\title{
CORRELATION OF CLIMATIC FACTORS WITH CEREAL CROPS YIELD: A STUDY FROM HISTORICAL DATA OF MORANG DISTRICT, NEPAL.
}

Badri Khanal $^{1}$

\begin{abstract}
The present study is based on the secondary sources of inforamation on temperature, rainfall and productivity of four major cereals ( Rice, Maize, Finger Millet and Wheat) in Morang district of Nepal. A total of 17 years data (1995-2011) on yield of crops, annual total rainfall, annual mean maximum temperature and annual mean minimum temperature is analysed. The suitability analysis of crops shows that all the four cereals found to be suitable for cultivation in temperature range of Morang district, whereas irrgigation is required in addition to recorded rainfall in case of rice and wheat. The production of three cereals except millet (which is almost stable) has increased during the study period. The analysis of correlation coefficient shows that maize yield and minimum temperature have strong positive correlation (0.7755). The linear regression analysis showed that the yield of maize was significant and highly sensitive to combined effect of all three climatic factors $\left(R^{2}\right.$ 0.7414). Whereas, the yield of rice, millet and wheat were not statistically significantly related. At individul climatic factors level, yield of maize and wheat were significantly related with annual mean minimum temperature. The yield of these crops can be increased by crop managementmainly by altering the planting time, varieties and irrigation practices.
\end{abstract}

Key words : cereals, correlation, rainfall, temperature, yield

\section{INTRODUCTION}

Globally many initiatives has been made in agriculture sector for betterment in farming technology and crop mangement practices. This is aimed to increase the crop productivity to ensure food security ofgrowing population. The climatic factors has always played the vital role in the productivity of the crops. This has drawn the attention of agriculturist in background of global warming and climate change. Hence, in country like Nepal where almost $34 \%$ of Gross Domestic Product (GDP) is contributed from agriculture sector (MOF,2014), the study of cliamtic factors to explain the crop yield is very important.

Analysis of climatic factors provides the level of association between crop and climate. Moreover, analyzing the impacts of historic climatic factors trends on crop production helps to identify the possible impacts of future climate, which also reviews the on-going efforts of adaptation and change in production. (Lobell and Field 2007; Lobell et al.2011).

One of the major climatic factor responsible for agricultural production is temperature (both maximum and minimum). According to IPCC 2007 the global average temperature has gone up by about $0.13^{\circ} \mathrm{C}$ per decade since 1950 . The study suggests that warming trends in the Himalayan region and nearby is significant, generally higher compared to global

\footnotetext{
${ }^{1}$ Agriculture Economist, Ministry of Agricultural Development, Email: badri.khanal1@gmail.com
} 
average (Shrestha et al. 1999; Hu et al.2011, 2013). The study also suggests that the rate of warming is most often increases with increased elevation (Sharma et al. 2009; Hu et al.2013).

The study from Bhatta et al. 2014 shows that the responses of crop yields to a unit increment in mean temperature of growing season vary from -6 to $16 \%,-4$ to $11 \%$ and -12 to $3 \%$ for three cereals, rice, maize and wheat, respectively, depending on the location and elevation in the Koshi basin of Nepal.

The review conducted by Malla, 2008, shows that $4^{\circ} \mathrm{C}$ increase in temperature drops rice yield by $3.4 \%$ in Terai, increase by $17.9 \%$ in hills and $36.1 \%$ increase in mountain. For same level of temperature drop there was 1.8\% decreases in yield in Terai but increase by $5.3 \%$ in the hill and $33.3 \%$ in Mountain in case of Wheat. In case of Maize, at $4^{\circ} \mathrm{C}$ temperature rise, the yield decline by $26.4 \%$ in terai, $9.3 \%$ in hills but increase by $26.8 \%$ in the Mountain. Increased temperature in sub-tropical region will decrease in potential wheat yield by $1.5-5.8 \%$ but will decrease by $17-18 \%$ in tropical zone (Agrawal and Kalra, 1994).

Similalrly, rainfall has imprortant role in rainfed agriculture like Nepal. Both the intensity and distribution of rainfall has effect on agriculture production. Drought has a negative impact on rural livelihoods that mainly depend upon rainfed subsistence agriculture. According to Thomas, 2008, drought is the major source of uncertainty in food production in Nepal and disturbs social harmony by creating water-use conflicts. A slight decrease in the rainfall and increase in temperature will have a negative impact in cereals yield which is a matter of great interest (Bhandari, 2013a).

The likely impact of climate in future on crop production is estimated by several studies. However, the impacts on production of crop due to historic climate trend are yet to be widely analysed (Lobell and Field 2007).

In this regard, the present study is aimed to fill the gap in exiting literature and provide a better reference for future analysis using informations for cereals crop yield and temperature and rainfall of one of the potential cereals producing district -Morang for year 1995-2011.The main impetus of present study is to examine the climate-crop yield relationships and to study the impact of historic trends of climatic factors on yield of rice, maize, finger millet and wheat in the Morang district of Nepal. This gives the idea on how production of selected cereals ( Rice, Maize,Finger Millet and Wheat) is associated with these climatic factors. 


\section{MATERIALS AND METHODS}

\section{STUDY AREA}

Morang district lies in Terai of Nepal in Eastern Development Region. The total area of the district is 1,855 Square Kilometer of which, almost $80 \%$ of the area is plain and rest lies in Churia and Mahabharat Hill Range. The altitute of the district varies from 60 meter to 2,410 meter above mean sea level. The latitude of the district is $26.20^{\circ}-26.53^{\circ}$ East and Longitude is $87.16^{\circ}$ to $87.49^{\circ}$ North. The $56.5 \%$ of the total land is used for agriculture purpose and remaining for other purposes. The soil of the district are devided into three categories based on land, elevation and soil texture as Sandy loam (hill range); Loam and Clay (Chure range), and Sandy Clay Loam and Loam (Terai range). The major source of livelihood in district is agriculture, which contributes almost $37.48 \%$ of total Gross Domestic product of district ( BSO,2006).

\section{DATA}

The study is based on the secondary sources of information. The production and yield of the four cereals was collected from the various issues of "Statistical Information on Nepalese Agriculture", Ministry of Agricultural Development, Nepal (MoAD,2012). As, both the rice and maize are produced during two seasons in Morang (Spring and Summer), the total of these two is used for the study purpose. Similalry, the data regarding, annual rainfall, annual mean maximun temperature and annual mean minimum temperature was collected from Department of of Hydrology and Meterology Nepal (CBS,2008 ; CBS, 2011). All the information regard ing yield of crops and climatic information were collected for 17 years starting from 1995 to 2011 and analysed. All the other relevant informations were collected from other sources of information.

\section{ANALYTICAL FRAMEWORK}

The relationship between yield of major cereals and three climatic factors was analyzed through linear regression with the null hypothesis $(\mathrm{Ho})$ that there was no statistically significant correlation between climatic elements (rainfall and temperature) and yield of the crops. For this, first of all, Pearson correlation coefficient was calculated by examining degree association between different pairs of explanatory variables and between explanatory variables and dependent variables through zero order correlation matrixes. The sample correlation coefficient is

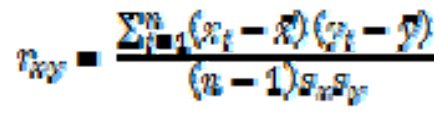

Where $\bar{x}$ and $\bar{y}$ are the sample means of $\mathrm{X}$ and $\mathrm{Y}, \boldsymbol{s}_{\mathrm{X}}$ ands. $s_{y}$ are the sample standard deviation of $\mathrm{X}$ and $\mathrm{Y}$. 
Linear regression model was used to estimate relationship between yield of rice, maize, millet and wheat and selected explanatory variables. Four linear models assumed for each crop, three for considering single variable and one for combined of all three variables. Thus, the linear function assumed for the present study was:

$Y=a+B_{1} X_{1}$

$Y=a^{\prime}+B_{2}^{\prime} X_{2}$

$Y=a+B^{\prime \prime} X_{3}$

$Y=a^{\prime \prime \prime}+B^{\prime \prime \prime}{ }_{1} X_{1}+B^{\prime \prime \prime}{ }_{2} X_{2}+B^{\prime \prime \prime}{ }_{3} X_{3}+\mu$

Where, $Y=$ yield of the crop

$X_{1}=$ annual rainfall $(\mathrm{mm})$

$\mathrm{X}_{2}=$ annual mean maximum temperature $\left({ }^{\circ} \mathrm{C}\right)$

$\mathrm{X}_{3}=$ annual mean minimum temperature $\left({ }^{\circ} \mathrm{C}\right)$

$\mu=$ disturbance or error term

$a=$ constant value and $B_{1}, B_{2}$ and $B_{3}$ are regression coefficients of the respective variables, whose significance is tested.

The overall significance of regressions was tested using f-test with ANOVA approach. The test consists of null hypothesis $\left(\mathrm{H}_{\mathrm{o}}\right)$ that all regression coefficients are simultaneously not statistically different from zero versus alternate hypothesis $\left(H_{1}\right)$ that all the regression coefficients ( $B$ 's) are statistically different from zero simultaneously. The test statistic used was f-test, which was calculated as:

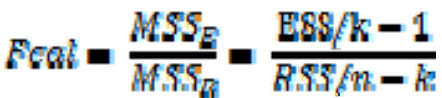

Where, ESS = regression sum of square; RSS= residual sum of square; $k-1$ is degree of freedom for regression and $n-k$ is degree of freedom for residuals where $n$ is number of observations and $k$ is numbers of explanatory variables.

\section{RESULTS AND DISCUSSION}

The suitability of all the four crops was tested through comparing the actual climatic factors of the Morang district with the cardinal climatic factors for the crops. The Table 1 gives the cardinal requirements of temperature and water, and actual value of rainfall and temperature during year 2010/2011(March 2010-April 2011).

The temperature and water requirement of the crops varies according to their growth stages. Rice can be grown in wide range of temperature ranging from $20-40^{\circ} \mathrm{C}$, however, $30-35^{\circ} \mathrm{C}$ for germination, $26.5-29.5^{\circ} \mathrm{C}$ during flowering and $20-25^{\circ} \mathrm{C}$ during the gain fill period is optimum. It can be grown as rainfed crop in area having $200 \mathrm{~cm}$ of well distributed rainfall. Mostly $80-200 \mathrm{~cm}$ of water is required for the crop. The optimum temperature for maize is $21^{\circ} \mathrm{C}$ for germination and $32^{\circ} \mathrm{C}$ for growth. Water requirement 
varies from $25 \mathrm{~cm}$ to $500 \mathrm{~cm}$. As finger millet is a hardy crop, it grows well in range of 12$45^{\circ} \mathrm{C}$ temperature, whereas optimum temperature is $18-27^{\circ} \mathrm{C}$, and the water requirement is $750 \mathrm{~mm}$. Wheat crop can be grown in a range of $3.5-35^{\circ} \mathrm{C}$, however, seed germination takes place well during $20-25^{\circ} \mathrm{C}$. Higher than $27^{\circ} \mathrm{C}$ is not good for anther formation and pollination. The temperature during the grain filling period should be less than $25^{\circ} \mathrm{C}$. The well distributed rainfall of $40-110 \mathrm{~cm}$ is enough for wheat crop.

As the temperature of the Morang district varies from 18.1 to $35.5^{\circ} \mathrm{C}$ during spring and 22$32.8^{\circ} \mathrm{C}$ during summer season, it is suitable area for cultivation of cereals like rice, maize and finger millet. Likewise, winter temperature varies from 8.8 to $33.1^{\circ} \mathrm{C}$ in which is also suitable for wheat crop. The water management for the crop depends upon the rainfall of the area. Mostly, the crop like rice and wheat requires the irrigation as water requirement of rice is high and there is low winter rainfall for wheat.

Table 1: The cardinal requirements of crops and recorded climatic factors of Morang district

\begin{tabular}{|c|c|c|c|c|c|c|c|c|}
\hline \multirow{3}{*}{$\begin{array}{l}\text { Cereal } \\
\text { Crops }\end{array}$} & \multicolumn{2}{|c|}{ Cardinal Requirements } & \multicolumn{6}{|c|}{ Climatic Factors in Year 2010/2011 } \\
\hline & \multirow{2}{*}{$\begin{array}{c}\text { temperature } \\
\text { Range }{ }^{0} \mathrm{C}\end{array}$} & \multirow{2}{*}{$\begin{array}{l}\text { Water } \\
\text { Level } \\
\text { mm }\end{array}$} & \multicolumn{2}{|c|}{$\begin{array}{c}\text { Spring crops } \\
\text { season (March- } \\
\text { June) }\end{array}$} & \multicolumn{2}{|c|}{$\begin{array}{l}\text { Summer / Kharif } \\
\text { crops season } \\
\text { (July-October) }\end{array}$} & \multicolumn{2}{|c|}{$\begin{array}{c}\text { Winter / Rabi crops } \\
\text { season } \\
\text { (November-April) }\end{array}$} \\
\hline & & & Temp $^{0} \mathrm{C}$ & $\begin{array}{c}\text { rainfall } \\
\mathrm{mm}\end{array}$ & Temp $^{0} \mathrm{C}$ & $\begin{array}{c}\text { rainfall } \\
\mathrm{mm}\end{array}$ & Temp $^{0} \mathrm{C}$ & rainfall \\
\hline Rice & $20-40^{*}$ & $\begin{array}{l}800- \\
2000^{*}\end{array}$ & $\begin{array}{l}18.1- \\
35.5\end{array}$ & 564.7 & $22-32.8$ & 1329.7 & & \\
\hline Maize & $20-35^{*}$ & $\begin{array}{l}250- \\
5000^{*}\end{array}$ & $\begin{array}{l}18.1- \\
35.5\end{array}$ & 564.7 & $22-32.8$ & 1329.7 & & \\
\hline Millet & $\begin{array}{l}18-27 \\
\text { (optimum) }^{* *}\end{array}$ & $700^{* *}$ & & & $22-32.8$ & 1329.7 & & \\
\hline Wheat & $3.5-35^{*}$ & $\begin{array}{l}400- \\
1100^{*}\end{array}$ & & & & & $\begin{array}{l}8.8- \\
33.1\end{array}$ & 23 \\
\hline
\end{tabular}

The production of all the selected cereals was increasing, except millet (which was almost stagnant over the years) however their growth rate was different. The rice growth rate was more prominent than others. The annual rainfall fluctuated between 1,300 $\mathrm{mm}$ to 2,677 $\mathrm{mm}$ during the period (Fig 2). Though the fluctuation in rainfall over the years was not explained much by the trend line (only $6 \%$ ), it was in decreasing trend in Morang district. 


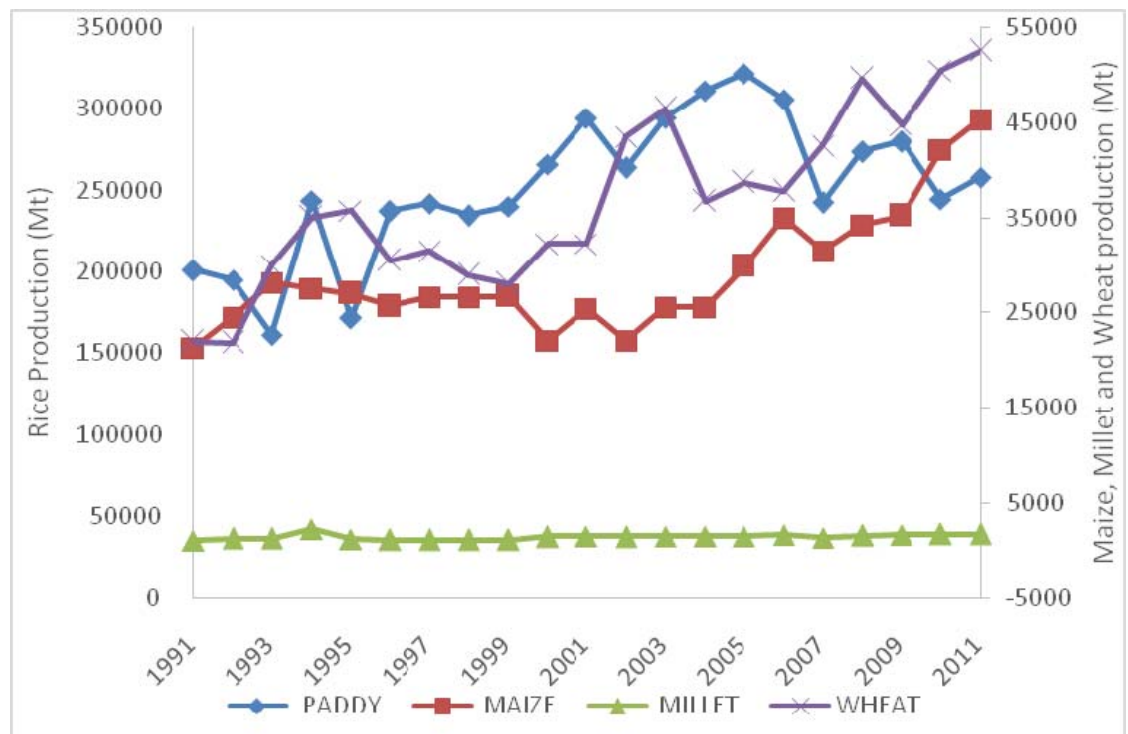

Fig 1: Production trend of major cereals in Morang district

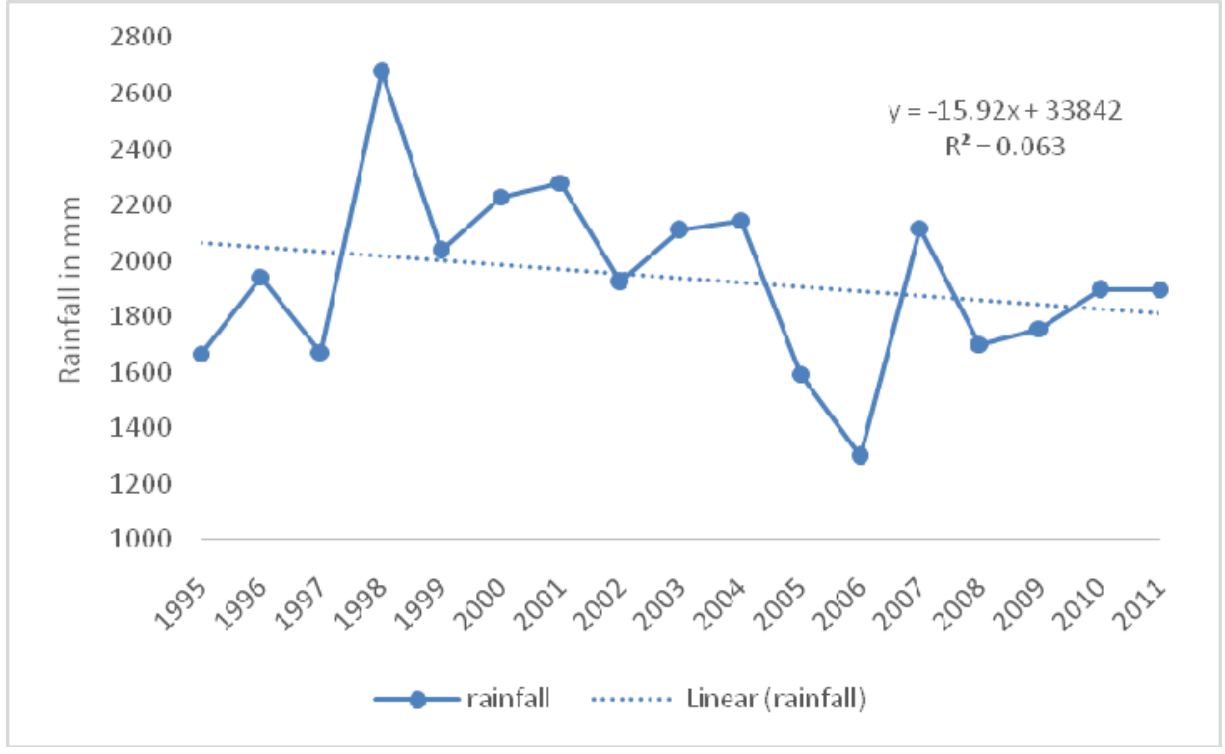

Fig 2: Trend of annual total rainfall over the years in Morang district

The mean maximum temperature from 1990 to 2011 varied from 29.5 to $30.9^{\circ} \mathrm{C}$ (Figure 3). The trend line showed that the maximum temperature was increasing over the year, though change was statistically not significant. 


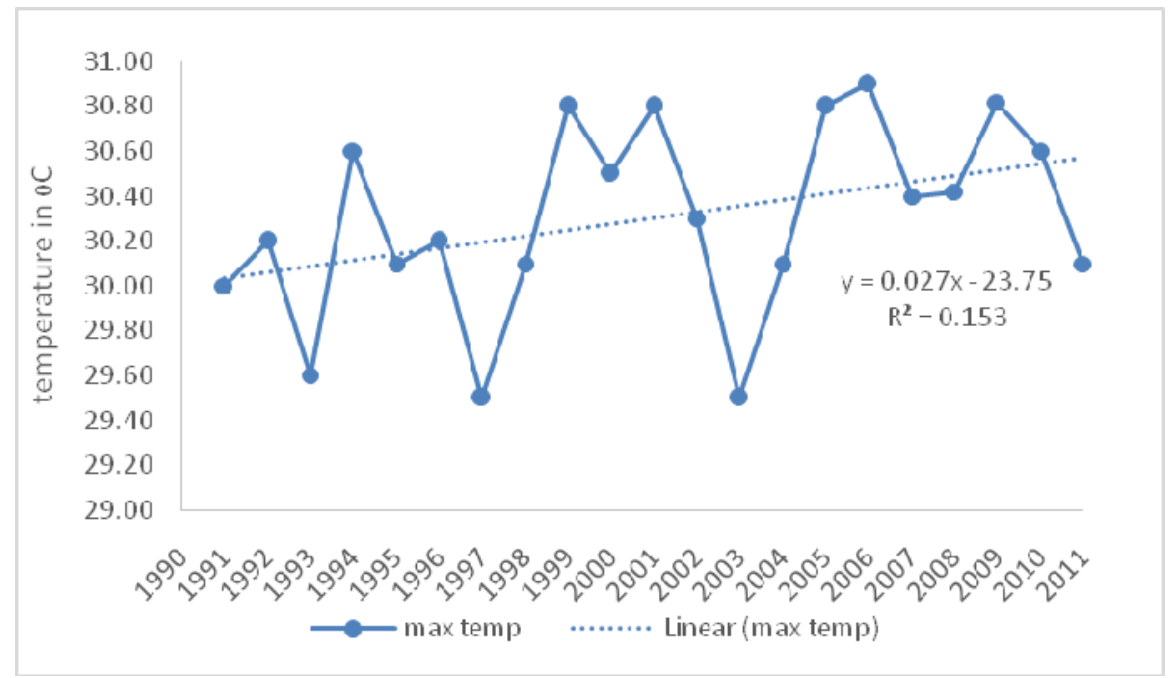

Fig 3: Trend of annual mean maximum temperature over the years in Morang district

The annual mean minimum temperature varied from 18.6 to $20.5^{\circ} \mathrm{C}$ during $1990-2011$. The trend line followed increase over the period and which was statistically significant.

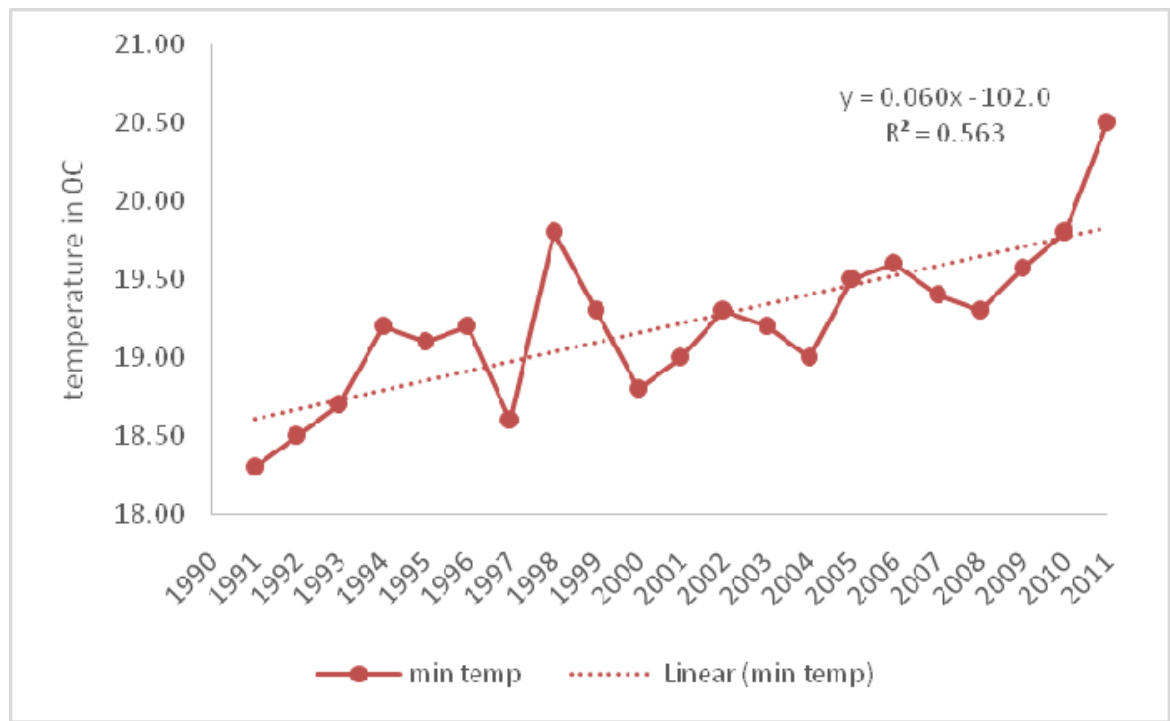

Fig 4: Trend of annualmeanminimum temperature, over the years in Morang district 


\section{RICE}

The correlation coefficient between rice yield and rainfall showed negligible negative correlation (-0.14) which was not statistically significant at the 0.05 level since the P-value is greater than 0.05 . It indicated that there was no correlation between rainfall and rice yield.

Regression analysis indicated that rainfall explains only $2.01 \%$ of rice yield $\left(R^{2}=0.0201\right)$. The regression equation is

$Y=3231.2+(-0.15)^{*}$ rainfall

There was non-significant negligible positive correlation and weak positive correlation in between rice yield and the mean annual maximum temperature $(0.27)$ and mean annual minimum temperature $(0.37)$, respectively as the measured $P$ value is greater than tabulated value at 0.05 confident level.

The regression analysis did not support relationship between mean annual maximum temperature and rice yield. The result shows that mean annual maximum temperature $\left(R=0.27, R^{2}=0.75\right)$ and mean annual minimum temperature $\left(R=0.36, R^{2}=0.135\right)$ explained only 7.5 and $13.5 \%$ of rice yield, respectively.

The regression equations are

$\mathrm{Y}=-3668.6+217.7 *$ mean annual maximum temperature

$\mathrm{Y}=-2529.1+282.5 *$ mean annual minimum temperature

The combined effect of all the three variables namely annual rainfall, mean annual maximum and minimum temperature showed the $P$ value of 0.4460 which is greater than 0.05 . This accepts the null hypothesis, hence concluded that the combined effect of these three variables had no significant correlation with rice yield. Only $17.95 \%$ of rice yield could be explained by combination of all three variables.

The regression equation is given as:

$\mathrm{Y}=-5989.4+(-0.0997)^{*}$ annual rainfall +142.94 * mean annual maximum Temp +247.13 * mean annual minimum temperature +341.67

\section{MAIZE}

The analysis showed that correlation coefficient between maize yield and annual rainfall, annual mean maximum temperature and mean minimum temperature had non-significant weak negative $(-0.39)$, non-significant negligible positive $(0.15)$ and significant strong positive $(0.77)$ correlations, respectively. The regression results showed that annual 
rainfall, mean annual maximum temperature and men annual minimum temperature explained $15.07,2.3$ and $60 \%$ of maize yield, respectively.

The regression equations for different climatic variables are as follows

$\mathrm{Y}=2733.1+(-0.38)^{*}$ annual rainfall

$Y=-1375.25+110.845 *$ mean annual maximum temperature

$Y=-8752.08+554.988 *$ mean annual minimum temperature

The combined effect of all the three variables namely annual rainfall, mean annual maximum and minimum temperature showed calculated P-value of 0.0004 which was less than tabulated value. This rejects the null hypothesis and concluded that the combined effect of all three variables had significant correlation with maize yield. The $\mathrm{R}$ square value of combined all three factors was 0.74 , which means $74.14 \%$ of maize yield was explained by combined effect of the three climatic variables

The Regression equation is given as:

$\mathrm{Y}=-5698.6+(-0.37)^{*}$ annual rainfall $+(-81.8){ }^{*}$ mean annual maximum temperature +563. $3 *$ mean annual minimum temperature +177.77

\section{MILLET}

In case of millet, the analysis revealed that correlation coefficient between millet yield and annual rainfall, annual mean maximum temperature and mean minimum temperature had non-significant weak negative $(-0.39)$, non-significant weak positive $(0.30)$ and nonsignificant weakly positive $(0.36)$ correlations, respectively. The regression results showed that annual rainfall, mean annual maximum temperature and mean annual minimum temperature explained $9.4,9.3$ and $24.3 \%$ of millet yield, respectively.

The regression equations for all the three variables are as follows

$\mathrm{Y}=1310.2+(-0.121)^{*}$ annual rainfall

$Y=-1646.4+89.70 *$ mean annual maximum temperature

$Y=-892.8346+101.72 *$ mean annual minimum temperature

As the P-value $(0.2916)$ for combined three variables was greater than tabulated value at 0.05 level, therefore the null hypothesis was accepted. Thus, the combined effect of annual rainfall, mean annual maximum and mean annual minimum temperature had no significant correlation with millet yield. Only $24.21 \%$ of millet yield was explained by annual rainfall, mean annual maximum temperature and mean annual minimum temperature. The Regression equation is given as: 
$\mathrm{Y}=-2026+(-0.102)^{*}$ annual rainfall +53.45 * mean annual maximum temperature +86.71 * mean annual minimum temperature +121.59

\section{WHEAT}

In the case of wheat, its yield had non-significant weakly negative $(-0.26)$, non-significant negligible positive $(0.19)$ and non-significant weakly positive $(0.49)$ correlations with annual rainfall, mean annual maximum temperature and mean annual minimum temperature, respectively. The regression results showed that annual rainfall, mean annual maximum temperature and mean annual minimum temperature explained 6.5, 3.5 and 23.9 $\%$ of wheat yield, respectively.

The regression equations are as follows is

$Y=2450.6+(-0.19)^{*}$ annual rainfall

$Y=-1065.8+103.7 *$ mean annual maximum temperature

$Y=-2993.6+262.23 *$ mean annual minimum temperature

When the three variables rainfall, maximum and minimum temperature were combined for analysis, the calculated $P$ value $(0.1919)$ was greater than tabulated value at $0.05 \%$ confident level. This accepted the null hypothesis and concluded that the combined effect of these three variables had no significant correlation with wheat yield. The $\mathrm{R}$ square value of combined all three factors was calculated as 0.30 , which meant only $30 \%$ of wheat yield was explained by effect of annual rainfall, mean annual maximum temperature and mean annual minimum temperature together in combination. The regression equation is given as:

$\mathrm{Y}=-2997.7+(-0.17)^{*}$ annual rainfall +16.56 * mean annual maximum temperature + 253.76 *mean annual minimum temperature +219.67

\section{CONCLUSION}

The suitability analysis of selected crops shows that, all the four cereals of the study namely rice, maize, millet and wheat) are suitable in climatic condition (temperature and rainfall) of Morang district. The crops like rice and wheat requires more water than rainfall of the area, which necessitate additional irrigation. The yield of three major cereals rice, maize and wheat was found to be increasing over the years. However, millet production was almost unchanged. The correlation coefficient between rice yield and climatic factors showed that only mean annual minimum temperature had correlated with weak association. In case of maize, annual rainfall and mean annual minimum temperature had correlated with yield. The correlation between mean annual minimum temperature and rainfall had strong positive correlation $(0.77)$. In case of millet all the three factors were weakly correlated with yield. Wheat yield had weakly correlated only with mean annual minimum temperature. 
The result concludes that the mean annual minimum temperature explains the larger portion of the crop yield variation than both the mean annual maximum temperature and annual rainfall in all the four cereals. But, the annual rainfall contributed higher in the yield of rice, millet and wheat than mean annual maximum temperature, whereas the reverse was found in case of maize. Though, the only maize crop was found to be significantly explaining the crop yield by combined of all the variables i.e. annual rainfall, mean annual maximum temperature and minimum temperature, remaining crops yield were also defined by few proportion by these factors. The rainfall and mean annual maximum temperature was found to be not significantly explaining yield of all the crops.

Thus, the study of these factors is helpful to identify relationship between the climatic factors and yield potentiality of crop. The yield of these crops can be increased by altering the plantation date, choosing the suitable varieties, managing the irrigation facility, and other improved technologies based on the established relationship of crop and climatic factors.

\section{REFERENCES}

Agrawal, P. K. and N. Kalra, 1994. Analysing the limitation set by climate factors, genotype, and water and nitrogen availability on productivity of wheat II. Climatically potential yield and optimal management strategies. Field Crop Res. 38:93-103

Bhandari, G., 2013a. Effect of precipitation and temperature variation on the yield of major cereals in Dadeldhura district of far western development region, Nepal. International Journal of Plant, Animal and Environmental Sciences (IJPAES), India, Vol: 3, Issue: 01, ISSN:2231-4490 (Online), pp. 247-256.

Bhandari, G., 2013b. Impact of rainfall and temperature on yield of Major Cereals in Jumla district, Nepal. Persian Gulf Crop Protection, 2(4), pp 35-44.

Bhatt D, Maskey S, Bable M S, Mukand S., Uhlenbrook S, Prasad KC, 2014, Climate trends and impacts on crop production in the KoshiRiver basin of Nepal, Reg Environ Change (2014) 14:1291-1301, DOI 10.1007/s10113-013-0576-6

BSO, 2006.district Profile of Morang district, Branch Statistical Office, Morang, Nepal

CBS, 2008. Environment Statistics of Nepal, Central Bureau of Statistics, Nepal, 2008

CBS, 2011. Environment Statistics of Nepal, Central Bureau of Statistics, Nepal, 2011

Hu Y, Maskey S, Uhlenbrook S 2011. Trends in temperature andrainfall extremes in the Yellow River source region, China. ClimChang 110:403-429

Hu Y, Maskey S, Uhlenbrook S, 2013. Expected changes in futuretemperature extremes and their elevation dependency over the Yellow River source region. Hydrol Earth SystSci17:2501-2514

IPCC (Intergovernmental Panel on Climate Change), 2007a. Climate change 2007: The physical science basis. In: Solomon S, Qin D, Manning M, Chen Z, Marquis M, Averyt KB, Tignor M, 
MillerHL (eds) Contribution of working group I to the fourthassessment report of the intergovernmental panel on climatechange. Cambridge University Press, Cambridge.

Lobell DB, Cahill K, Field C (2007) Historical effects of temperatureand precipitation on California crop yields. Clim Chang 81:187-203

Lobell DB, Schlenker W, Costa-Roberts J (2011) Climate trends andglobal crop production since 1980. Science 333:616-620

Malla, G. 2008, Climate change and its impact on Nepalese Agriculture, the Journal of Agriculture and Environment, vol:9, Jun, 2008, PP:62-71.

MoAD, 2012, Statistical Information on Nepalese Agriculture (various issues), Ministry of Agricultural Development

MoF, 2014, Economic Survey, Ministry of Finance, Government of Nepal, 2014

Sharma E, Chettri N, Tse-ring K, Shrestha AB, Fang J, Mool P, Eriksson M ,2009. Climate change impacts and vulnerability inthe Eastern Himalayas. ICIMOD, Kathmandu

Shrestha AB, Wake CP, Mayewski PA, Dibb JE,1999. Maximum temperature trends in the Himalaya and its vicinity: an analysisbased on temperature records from Nepal for the period1971-94. J Clim $12: 2775-2787$

Thomas, R.J., 2008. Opportunities to reduce the vulnerability of dry land farmers in Central and West Asia and North Africa to climate change. Agric Ecosystem Environ. 126(1-2):36-45.

www.plantvillage.com/en/topics/finger-

millet/infos/diseases_and_pests_description_uses_propagation 